\title{
SUBSIDISED ELECTRICITY TAX ON BIOGAS PRODUCTION IN LATVIA
}

\begin{abstract}
Mareks RUBĪNS, Institute of Economics and regional development, Faculty of Economics Latvia University of Agriculture, Address: 2 Liela Street, Jelgava, LV-3001, Latvia; mareks.rubins@1lu.lv (corresponding author)

Irina PILVERE, Institute of Economics and regional development, Faculty of Economics Latvia University of Agriculture, Address: 2 Liela Street, Jelgava, LV-3001, Latvia; Country; irina.pilvere@1lu.lv

Biogas production becomes increasingly popular in Latvia. The development of the biogas industry depends on national and European Union (EU) support, as biogas production is not economically efficient without the support. In 2014 Latvia introduced a new tax - the subsidized energy tax (SET) - that influences all biogas producers in the country. A 10\% tax rate is applied to incomes gained from: 1) electricity sold under the mandatory purchase obligation; 2) guaranteed payments for the electrical capacity installed in a cogeneration plant or a power plant. However, there is an opportunity to apply the reduced SET rate of 5\%. This is a government support scheme that may be applied to the tax payers that meet the criteria for effective thermal energy use: the operation of biogas facilities, the production of products or their sale to a related person, thereby ensuring the operation of the enterprise. For this purpose, the biogas facility has to be equipped with meters for measuring thermal energy generated; accurate readings of the meters at the generator output have to be specified in monthly tax reports. The research analyzed the fiscal effects of the SET on biogas production enterprises and opportunities for the reduced SET rate to be applied. The reduced SET rate is paid by 29 out of 61 (28\%) biogas producers listed in the Register of Subsidized Electricity Producers. The research employed analysis and synthesis, logical construction, the monographic method and statistical analysis and performed calculations. The authors assessed the situation at four biogas production enterprises that were different in terms of output capacity and inputs used. An analysis of gross profit margins allowed concluding that there were considerable differences in expected gross profit margin among various producers: from 13\% to 50\%, which would be able to influence their decisions to construct a biogas facility if the SET situation were known.
\end{abstract}

Keywords: biogas production, subsidized energy tax, expected profit

\section{INTRODUCTION}

Biogases consist of methane (50-70\%), carbon dioxide (30-40\%) and other gases in lower concentrations. Biogas could be produced almost from any organic substance that is produced or originated in the primary agricultural sector. Biogas is also produced from industrial and household waste. Biogas also forms in nature, while the industrial production of biogas requires a complicated and complex facility, which makes biogas production a quite expensive process. In biogas production, organic substances are processed in a bioreactor in the anaerobic fermentation process (Ahlberg-Eliasson, 2016; Biogāzes ražošanas..., 2007; Rubins, 2014). A biogas facility consists of: a biomass accumulation system, equipment for biomass processing and a biogas accumulation and purification system. Particularly such complicated facilities need government support, as without the support biogas production is not economically feasible. The cost can exceed the revenue (Biogāzes ražošanas..., 2007; Agostini, 2016). Biogas production is a sustainable and environment-friendly kind of energy production that decreases greenhouse gas (GHG) emissions. Biogas production involves anaerobic fermentation that decreases the amount of methane released into the atmosphere (Mohammed, 2016). The EU Member States have made commitments both to increase the share of electricity from renewable energy sources (RES) in final consumption and to reduce GHG emissions. In a long-term, by increasing the agricultural productivity and efficiency in Latvia at least to the EU-12 level, it is possible both to double the output of food and to increase the output of electricity produced from biomass of agricultural origin 22 times compared with the present level. There is potential and a possibility in Latvia to develop not only food production, but also renewable energy resources (Pilvere, 2012).

For these reasons, government support is necessary for biogas production (Agostini, 2016; Energētikas attīstības..., 2016). However, the level of support should be such as to motivate an investor to implement a project of electricity production from RES and, at the same time, no excessive profit is earned by the investor (Denina, 2008). Latvia has introduced a government support mechanism for the promotion of renewable energy production - mandatory procurement and guaranteed payments for the installed electric capacity. In Latvia, costs arising from supporting electricity produced from RES or in high efficiency cogeneration are covered by all final electricity consumers proportionally to their electricity consumption, as the mandatory procurement component (MPC) is integrated in the

Copyright (C) 2017 The Authors. Published by Aleksandras Stulginskis University. This is an open-access article distributed under the terms of the Creative Commons Attribution License (CC-BY 4.0), which permits unrestricted use, distribution, and reproduction in any medium, provided the original author and source are credited. 
price on electricity (Atjaunojamo energoresursu..., 2006). For this reason, a part of the public is dissatisfied with the fact that RES producers are too generously supported, which negatively influences households and businesses in Latvia. To decrease the effect of RES support on the final electricity price, in 2014 the SET at a rate of $10 \%$ (5\% reduced rate) was imposed on taxable revenues from electricity production (Subsidised Electricity..., 2014). Since the SET came into force after the majority of biogas producers in Latvia had made their decisions to start up biogas production, the effects of the SET on the expected financial performance of the biogas producers has to be examined to comprehend whether an enterprise would make a decision to construct a biogas facility if the enterprise were informed about the introduction of the SET.

Research object: indicators of biogas production enterprises

Research aim: to characterise eligibility opportunities for the reduced SET rate and to assess the fiscal effects of the SET on the expected financial performance of biogas producers. To achieve the aim, the following specific research tasks were defined: 1) to describe the SET and to analyse eligibility opportunities for the reduced SET rate; 2) to characterise the electricity feed-in tariffs and to analyse the effects of the SET on the expected financial performance of selected biogas producers.

\section{RESEARCH METHODS}

The research employed analysis and synthesis, logical construction, the monographic method and statistical analysis and performed calculations.

The authors assessed the situation at four biogas production enterprises that were different in terms of output capacity and inputs used. Data on expected annual revenues after project implementation (commencement of biogas production) were analysed to understand whether the enterprise management would have made a decision to construct a biogas facility if they were informed about the SET. Since the criteria for tax rates might change and were not known at the period of construction of biogas facilities, the authors assessed how all the four enterprises would be affected by both the 5\% and the 10\% SET rate. The data were acquired from the Rural Support Service (RSS) that administrated the application of the reduced SET rate. The names of the enterprises are not disclosed because of information confidentiality reasons.

$$
\text { Gross profit margin }=\text { Gross profit or loss } / \text { Net turnover } * 100 \%
$$

\section{RESEARCH RESULTS}

\section{Characteristics of the SET and the opportunity to pay the reduced SET rate}

The SET Law prescribes the object of the subsidised electricity tax, taxpayers, the tax rate, procedures for creating and maintaining a register of subsidised electricity producers (SEP), procedures for calculating, paying and administering the tax, as well as liability for violating this Law (Subsidised Electricity..., 2014). SET taxpayers are producers of electricity who have the following rights: to sell electricity within the scope of mandatory procurement; to receive guaranteed payment for the electric capacity installed in a cogeneration unit or power plant; to sell electricity in accordance with the conditions of Section 40 of the Energy Law that were in force in the time period from 6 October 1998 until 7 June 2005. In accordance with Section 6 of the Law, the Ministry of Economics is responsible for creating and maintaining the register of subsidised energy producers, in which 59 biogas power plants were listed (Subsidētās elektroenergijijas..., 2017).

Biogas producers that can meet the criteria set in Paragraphs 3, 4 and 6 of Section 5 of the Subsidised Electricity Tax Law are eligible for the 5\% SET rate. To receive SET tax relief, producers of electricity have to fill in an application and submit it to the RSS, proving that they have met the eligibility criteria (Table 1) and information about de minimis support received (Subsidētās elektroenergijas..., 2017; Lauku atbalsta..., 2014). In Latvia, 21 biogas producers or 34\% of their total paid the reduced SET rate in accordance with Paragraph 4 of Section 5 of the SET Law, 6 or $10 \%$ paid the reduced SET rate in accordance with Paragraph 3 of Section 5 of the SET Law, while only two biogas producers received SET relief in accordance with Paragraph 6 of Section 5 of the SET Law. In total, 61 biogas producers whose total installed capacity was $63.15 \mathrm{MW}$ were listed in the SEP register, of which 29 with a total capacity of $26.02 \mathrm{MW}$ paid the reduced SET rate. In total in 2017, 48\% of biogas producers paid the reduced SET rate, which was $4 \%$ more than in 2015 . Their total capacity comprised $41 \%$ of the total capacity of biogas producers (Subsidised Electricity..., 2014; Subsidētās elektroenerǵijas..., 2017).

\section{Effects of the SET on the expected financial performance of biogas producers}

In 2016 total revenues from electricity before SET of biogas producers in Latvia was 61.49 million euros. (Fig. 1). In $201678 \%$ (maximum $85 \%$, minimum $60 \%$ ) before SET and $70 \%$ (maximum $77 \%$, minimum 50\%) after SET from revenue form electricity of biogas producers was government support above market price. It shows how important government support is for biogas production. In 2016 SET reduced revenue from electricity of biogas producers by $8 \%$. Importance of reduction should be evaluated at producers' level, in order to measure profitability of biogas producers. 
Table 1. Opportunities for SET relief for biogas producers in Latvia

\begin{tabular}{|c|c|c|c|}
\hline $\begin{array}{l}\text { Section and } \\
\text { paragraph of } \\
\text { the SET Law }\end{array}$ & $\begin{array}{l}\text { Eligibility criteria to be simultaneously met in accordance with the relevant } \\
\text { paragraph of Section } 5 \text { of the SET Law }\end{array}$ & $\begin{array}{l}\text { Number of } \\
\text { biogas } \\
\text { producers } \\
\text { receiving } \\
\text { tax relief }\end{array}$ & $\begin{array}{l}\text { As a \% of } \\
\text { the total } \\
\text { biogas } \\
\text { producers } \\
\text { listed in the } \\
\text { SEP Register }\end{array}$ \\
\hline $\begin{array}{l}\text { Paragraph } 3 \\
\text { of Section } 5\end{array}$ & $\begin{array}{l}\text { 1) electricity was produced in high efficiency cogeneration units with installed } \\
\text { electric capacity not exceeding } 4 \text { megawatts in cogeneration units of natural gas, } \\
\text { or without restriction of installed electric capacity in cogeneration units of } \\
\text { renewable energy resources; 2) the taxpayer sells at least } 70 \text { per cent of thermal } \\
\text { energy obtained as a result of cogeneration process during a taxation year as a } \\
\text { heating system transmission or distribution merchant licensed by the Public } \\
\text { Utilities Commission or transfers to another heating system transmission or } \\
\text { distribution merchant licensed by the Regulator or local government that } \\
\text { provides services of centralised heating system. }\end{array}$ & 6 & $10 \%$ \\
\hline $\begin{array}{l}\text { Paragraph } 4 \\
\text { of Section } 5\end{array}$ & $\begin{array}{l}\text { 1) electricity was produced in high efficiency cogeneration units with installed } \\
\text { electric capacity not exceeding } 4 \text { megawatts; } 2 \text { ) not less than } 30 \text { per cent of by- } \\
\text { products or derived products of animal origin have been used for the production } \\
\text { of electricity; } 3 \text { ) not less than } 70 \text { per cent of the total raw materials has been } \\
\text { ensured by the taxpayer or it has purchased the necessary raw materials from a } \\
\text { producer who owns not less than } 50 \text { per cent of the equity capital shares of the } \\
\text { taxpayer; } 4 \text { ) the taxpayer uses the produced thermal energy for the production of } \\
\text { its produce or sells to a producer which is considered the related party in relation } \\
\text { to the taxpayer within the meaning of the Law On Taxes and Fees and which } \\
\text { uses it for the production of its produce. }\end{array}$ & 21 & $35 \%$ \\
\hline $\begin{array}{l}\text { Paragraph } 6 \\
\text { of Section } 5\end{array}$ & $\begin{array}{l}\text { 1) electricity was produced in high efficiency cogeneration units with installed } \\
\text { electric capacity not exceeding } 4 \text { megawatts in cogeneration units of natural gas, } \\
\text { or without restriction of installed electric capacity in cogeneration units of } \\
\text { renewable energy resources; 2) electricity was produced from fossil energy } \\
\text { resources (natural gas) or biogas; } 3 \text { ) the taxpayer uses not less than } 70 \text { per cent } \\
\text { of the thermal energy obtained as a result of cogeneration, which is remaining } \\
\text { after energy consumption of the main units producing or transforming energy, } \\
\text { for ensuring the plant vegetation process in covered areas, the total area of } \\
\text { which is not less than } 5000 \text { square metres, or supplies to a producer which is } \\
\text { considered the related party in relation to the taxpayer within the meaning of the } \\
\text { Law On Taxes and Fees and which uses the produced thermal energy for } \\
\text { ensuring the plant vegetation process in covered areas, the total area of which is } \\
\text { not less than } 5000 \text { square metres. }\end{array}$ & 2 & $3 \%$ \\
\hline \multicolumn{2}{|c|}{ Total: } & 29 & $48 \%$ \\
\hline
\end{tabular}

Source: Subsidised Electricity, 2014; Subsidētās elektroenerğijas..., 2017

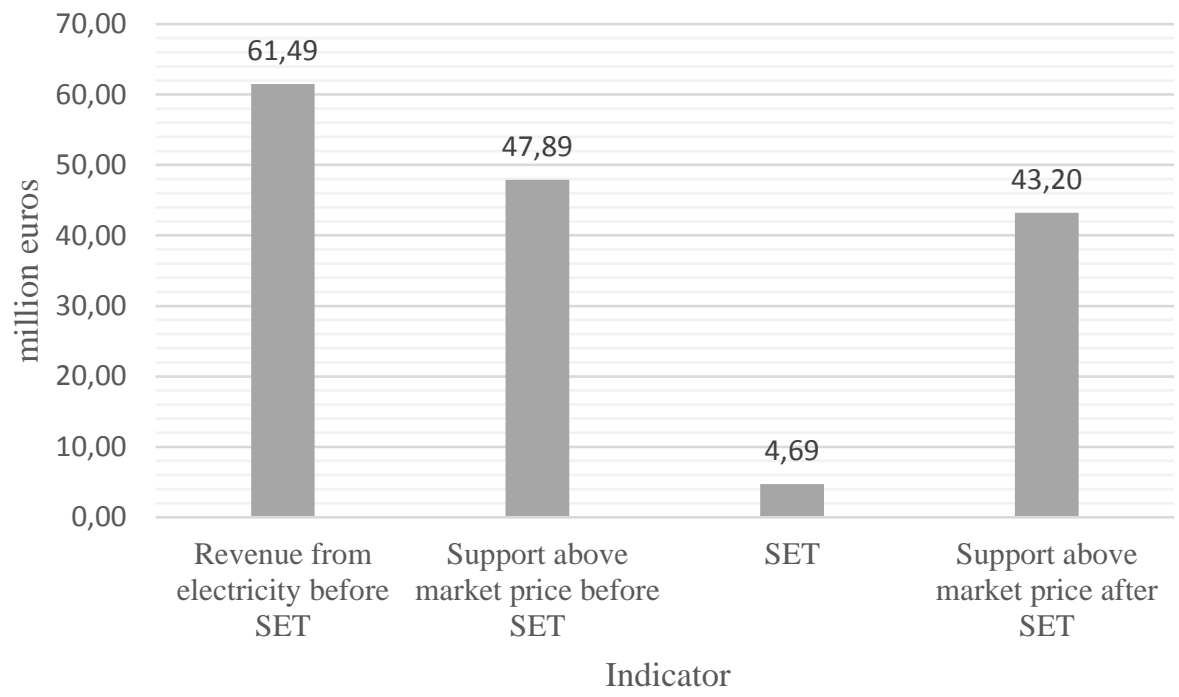

Source: Komersantiem 2016.gadā..., 2017

Figure 1. Revenue from electricity of biogas producers in Latvia 2016, million euros

Authors evaluate profitability of 4 different biogas producers. Indicators at four biogas production enterprises see in Table 2. Gross profit were different for various biogas producers and varied from 73574.00 EUR to 628566.00 EUR. 
Table 2. Annual financial effects of the SET on enterprises $x, y, w, z$ in Latvia after their project implementation, EUR

\begin{tabular}{|l|r|r|r|r|}
\hline \multicolumn{1}{|c|}{ Indicator } & \multicolumn{3}{c|}{ Enterprise } \\
\cline { 2 - 5 } & \multicolumn{1}{c|}{$\mathbf{x}$} & \multicolumn{1}{c|}{$\mathbf{y}$} & \multicolumn{1}{c|}{$\mathbf{z}$} & \multicolumn{1}{c|}{ w } \\
\hline Net turnover & 1251131 & 4762577 & 990783 & 339184 \\
\hline Gross profit & 628566 & 600833 & 495677 & 73574 \\
\hline Gross profit if a 5\% SET rate is applied & 576447 & 538252 & 463459 & 63183 \\
\hline Gross profit if a 10\% SET rate is applied & 524327 & 475671 & 431240 & 52792 \\
\hline
\end{tabular}

Source: (Rubins, 2014; Biogāzes ražotāju..., 2013)

Enterprise $\mathrm{x}$ produces electricity from biogas, and its capacity is $1 \mathrm{MW}$. This farm produces biogas from manure and silage. The profit after taxes of enterprise $x$ decreases by EUR 52 thou. at a 5\% SET rate and by EUR 104 thou. at a $10 \%$ SET rate. The gross profit margin decreases by $2.16 \%$-points at a 5\% SET rate and by $2.35 \%$-points at a $10 \%$ SET rate. Since its gross profit remains high even at a 10\% SET rate, the SET would not affect the choice of the producer to start-up a biogas business if the producer were informed about the SET before making a decision on the construction of a biogas facility (Table 3).

Enterprise y has a biogas facility with a capacity of $1 \mathrm{MW}$, and it produces biogas from cattle manure and maize silage; the enterprise uses its own inputs and in addition is engaged in agricultural production. The profit after taxes of enterprise y decreases by EUR 63 thou. at a 5\% SET rate and by EUR 125 thou. at a $10 \%$ SET rate. The gross profit margin decreases by $1.17 \%$-points at a $5 \%$ SET rate and by $2.22 \%$-points at a $10 \%$ SET rate. Since its gross profit margin was expected to be $12.62 \%$, and it could additionally decrease by $2 \%$-points because of the tax, the introduction of the SET, probably, would have affected the choice of the producer to start-up a biogas business if the producer were informed about the SET before making a decision on the construction of a biogas facility. One can see that the overall profit margin is affected by agricultural production, as the profit margin for it is lower than for biogas production.

Enterprise $\mathrm{z}$ has a biogas facility with a capacity of $0.526 \mathrm{MW}$, and it produces biogas from maize silage, grass silage, potato parings, grain chaff and manure; $78 \%$ of the inputs are produced on the farm. The profit after taxes of enterprise $z$ decreases by EUR 32 thou. at a 5\% SET rate and by EUR 64 thou. at a 10\% SET rate. The gross profit margin decreases by $1.68 \%$-points at a $5 \%$ SET rate and by $1.80 \%$-points at a $10 \%$ SET rate. Since its gross profit remains high even at a $10 \%$ SET rate, the SET would not affect the choice of the producer to start-up a biogas business if the producer were informed about the SET before making a decision on the construction of a biogas facility.

Enterprise w produces biogas from pig liquid manure, and its biogas facility's capacity is $0.169 \mathrm{MW}$; the enterprise uses inputs produced by another enterprise. Enterprise w uses its thermal energy generated for raising pigs. The profit after taxes of enterprise $w$ decreases by EUR 10 thou. at a 5\% SET rate and by EUR 21 thou. at a $10 \%$ SET rate. The gross profit margin decreases by $2.44 \%$-points at a $5 \%$ SET rate and by $4.55 \%$-points at a $10 \%$ SET rate. Since its gross profit was expected to be EUR 59 thou. and it decreases by EUR 10 thou. at a 5\% SET rate, which is a 17\% decrease, and a decrease in profit would be more than a third at a 10\% SET rate, the introduction of the SET would be able to affect the choice of the producer to start-up a biogas business if the producer were informed about the SET before making a decision on the construction of a biogas facility. In this case, one has to take into account the fact that enterprise w processes its pig liquid manure because, in order to construct a new pig facility, it is required to specify how and where its pig liquid manure is processed, as this kind of manure is very harmful to the environment. Accordingly, in the authors' opinion, it would be necessary to make such facilities exempt from the SET, as the gain from tackling environmental problems is greater than the tax revenue collected.

Gross profit margins were different for various biogas producers and varied from $13 \%$ to $50 \%$ (Fig. 2).

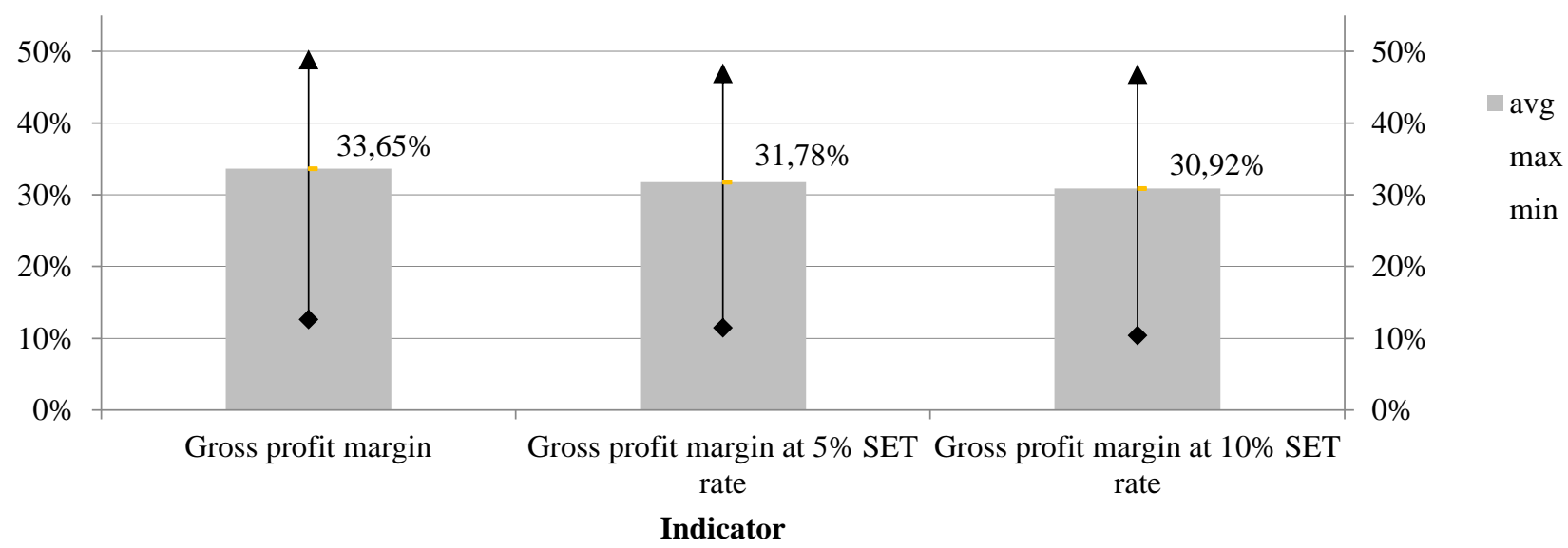

Source: authors' calculation

Figure 2. Expected gross profit margins for biogas producers in Latvia after their project

The calculations performed showed that the profit margins were very diverse, depending on the capacity of a biogas facility, inputs used and the way of acquisition of the inputs (produced on the farm or purchased). For this reason, 
for some enterprises SET is bigger issue than for others. It is likely that some enterprises would not make a decision to start-up a biogas business if they were informed about the introduction of the SET. The environment for entrepreneurship in the country has to stable and predictable.

It would be in the national interests to stimulate, by means of a lower SET rate, the use of inputs for biogas production that are the most environment-unfriendly (e.g. pig liquid manure). In the opinion of the authors, in case the SET is retained, the SET rates have to be made more different, e.g. if biogas is produced from inputs comprising $30 \%$ manure and more than $70 \%$ of thermal energy generated in biogas production is effectively used, the producers might be eligible for a $0 \%$ SET rate, which would motivate the biogas producers to make a greater contribution to environmental protection. In this case, biogas producers would be motivated to meet the eligibility criteria for a reduced SET rate.

\section{CONCLUSIONS}

1. On 1 January 2014 in Latvia, the Subsidised Electricity Tax Law came into force; it imposed a 5\% or $10 \%$ tax on electricity produced from biogas, thereby decreasing the feed-in tariff. It is positive that the reduced 5\% SET rate is paid by biogas producers that effectively use their thermal energy generated. In 2017, 29 or $48 \%$ biogas producers of 61 listed in the SEP Register paid the reduced SET rate, which was $4 \%$ more than in 2015 . Their total capacity comprised $41 \%$ of the total capacity of biogas producers. In the opinion of the authors, in case the SET is retained, the SET rates have to be made more different, e.g. if biogas is produced from inputs comprising 30\% manure and more than $70 \%$ of thermal energy generated in biogas production is effectively used, the producers might be eligible for a $0 \%$ SET rate, which would motivate the biogas producers to make a greater contribution to environmental protection.

2. In $201678 \%$ before SET and $70 \%$ after SET from revenue form electricity of biogas producers was government support above market price. It shows how important government support is for biogas production. The profit margins of biogas producers ranged from $13 \%$ to $50 \%$, depending on the capacity of a biogas facility, inputs used and the way of acquisition of the inputs (produced on the farm or purchased). For this reason, for some enterprises SET is bigger issue than for others, which has to be taken into account when introducing changes in support for biogas production in Latvia. In future, it is necessary to introduce new feed-in tariffs (through making new contracts with producers) that are economically feasible and set based on the kind of inputs used and can ensure motivating, balanced and fair profits and profit margins for the producers.

\section{REFERENCES}

1. Agostini, A., Battini, F., Padella, M. 2016. Economics of GHG emissions mitigation via biogas production from Sorghum, maize and dairy farm manure digestion in the Po valley. Available at: http://www.sciencedirect.com/science/article/pii/S0961953416300435 (Accessed on 27/10/2017).

2. Ahlberg-Eliasson K., Nadeau E., Leven L., et al. 2016.Production efficiency of Swedish farm-scale biogas plants. Available at: http://www.sciencedirect.com/science/article/pii/S0961953416303683 (Accessed on 15/09/2017).

3. Atjaunojamo energoresursu izmantošanas pamatnostādnes 2006 - 2013. gadam (Renewable Energy Guidelines 2006-2013). LV Ministry of Environmental Protection and Regional Development, 2006. Available at: www.vidm.gov.lv. (Accessed on 27/01/2017) [In Latvian]

4. Biogāzes ražošanas un izmantošanas veicināšanas programma 2007 - 2011. programmas projekts (Programme for the Promotion of Production and Use of Biogas 2007-2011). LV Ministry of Environmental Protection and Regional Development, 2007. (Available at: $\underline{w w w . v i d m . g o v . l v ~(A c c e s s e d ~ o n ~ 28 / 02 / 2017) ~[I n ~ L a t v i a n] ~}$

5. Biogāzes ražotāju plānotie finanšu dati: LAD nepublicētie dati (Expected Financial Performance of Biogas Producers: RSS unpublished data. Riga: Rural Support Service, LV Ministry of Agriculture, 2013. [In Latvian]

6. Denina, A. 2008Atjaunojamo energoresursu izmantosanas atbalsta shemas Eiropa un to ekonomiska efektivitate. Zinatniskais raksts (Support Schemes for Renewable Energy in Europe and their Economic Efficiency. Research paper). In: University of Latvia Proceedings. Vol. 737 Economics, VII. Riga: University of Latvia, pp. 88-100. [In Latvian]

7. Enerǵêtikas attīstības pamatnostādnes 2016.-2020. 2016. (Guidelines for Energy Sector Development 2016-2020). Available at: http://tap.mk.gov.lv/lv/mk/tap/?pid=40342629\&mode=mk\&date=2016-02-09 (Accessed on 22/12/2016) [In Latvian]

8. Komersantiem 2016.gadā obligātā iepirkuma ietvaros izmaksātās elektroenerǵijas naudas summas (Revenues paid to enterprises in the framework of mandatory procurement in 2016), 2017. Available at: https://www.em.gov.lv/files/energetika/2017-0213_11_30_13_OI_2016.xlsx (Accessed on 27/10/2016) [In Latvian]

9. Lauku atbalsta Dienests. SEN (Rural Support Service. SET), 2014. Available at: http://www.lad.gov.lv/lv/atbalstaveidi/noderigi/subsidetas-energijas-nodoklis/. (Accessed on 27/09/2017) [In Latvian]

10. Ministru kabineta 2010.gada 16.marta noteikumu Nr.262 Noteikumi par elektroenerǵijas ražošanu, izmantojot atjaunojamos energoresursus, un cenu noteikšanas kārtību (Cabinet Regulation No. 262 of 16 March 2010 "Regulations regarding Electrical Energy Production, Exploiting Renewable Sources, and the Procedure for Price Setting). Available at: https://likumi.lv/doc.php?id=207458 (Accessed on 27/10/2017) [In Latvian].

11. Mohammed M., Egyir I.S., Donkor A.K. 2016. Feasibility study for biogas integration into waste treatment plants in Ghana. Available at: http://www.sciencedirect.com/science/article/pii/S1110062116300940 (Accessed on 22/12/2016)

12. Pilvere I. 2012. Potential of Utilised Agricultural Area for Bioenergy Production: the Case of Latvia. 2012 AASRI Conference on Power and Energy Systems (PES 2012) AASRI Procedia 2, pp. 134-141. https://doi.org/10.1016/j.aasri.2012.09.025 
13. Rubins, M. Biogāzes ražošanas finansiālo aspektu analīze (Analysis of Financial Aspects in Biogas Production) (In Latvian). Riga: BA School of Business and Finance, 2014, 114 p. [In Latvian].

14. Subsidētās elektroenerǵijas nodokḷa likums un ražotāju reǵistrs (Subsidised Electricity Tax Law and the Register of Subsidised Electricity Producers).

LV Ministry

of

Economics,

2017.

Available

at: un_razotaju_registrs/ (Accessed on 25/10/2017) [In Latvian].

15. Subsidised Electricity Tax Law, 2014. Available at: https://likumi.lv/doc.php?id=262304 (Accessed on 15/01/2017). 